\title{
Wagner \& Nietzsche: The Concept of Evolution
}

\author{
H. James Birx ${ }^{1,2}-$ Branko Milićević ${ }^{3}$ \\ 1 University of Belgrade, Faculty of Philology, Studentski trg 3, 11000 Belgrade, Serbia \\ 2 Canisius College, Anthropology Division, 2001 Main Street, Buffalo, New York 14208-1098 USA \\ 3 BM Studio, Photography School of Belgrade, Serbia
}

Received $27^{\text {th }}$ January 2016; accepted $15^{\text {th }}$ September 2016

\section{WAGNER A NIETZSCHE: KONCEPT EVOLUCE}

ABSTRAKT Wagnerova tetralogie Prsten Nibelungů a Nietzschův dynamický pohled na svět odrážely nově se formující paradigma evoluce, věnovaly totiž náležitou pozornost konceptům času a změny s jejich dalekosáhlými důsledky. Oba géniové tvořivosti uznávali boje a konflikty, zcela prostupující sociální bytí a očekávali, že lidstvo bude postaveno před výzvu, která převrátí naruby tradiční hodnoty. Přitom však zdůrazňovali sílu vủle a přetrvání života. Díky Wagnerovi a Nietzschovi zahrnula Darwinova perspektiva evoluce jak umění, tak filozofii; vzniká nový model vesmíru. Wagner sice se smrtí hrdiny Siegfrieda předjímal konec lidstva, Nietzche si však představuje naplnění poslání našeho druhu v budoucím př́íchodu nadřazeného nadčlověka, který je cílem pokračující pozemské evoluce.

KLÍČOVÁ SLOVA ～změna; Darwin; evoluce; nadčlověk; filozofie; cyklus Prsten Nibelungư; čas; vesmír; hodnoty; vůle

ABSTRACT Grasping the far-reaching consequences of taking time and change seriously, both Richard Wagner's Ring tetralogy and Friedrich Nietzsche's dynamic worldview reflected the emerging evolutionary framework. Each creative genius acknowledged the pervasive struggles and conflicts within social existence, while anticipating a devastating challenge to traditional values and emphasizing the power of the will and an affirmation of life. With them, the perspective of Darwinian evolution now encompassed both art and philosophy; a new model of this universe is offered. Although Wagner saw humankind ending with the death of the hero Siegfried, Nietzsche envisioned the fulfillment of our species in the future appearance of the superior overhuman as the goal of ongoing evolution on our earth.

KEY WORDS Change; Darwin; Evolution; Overhuman; Philosophy; Ring operas; Time; Universe; Values; Will

\section{PROLOGUE: WAGNER \& NIETZSCHE}

In terms of ideas, one may argue that Charles Darwin (18091882) was the central thinker of the nineteenth century. He had brought about an intellectual revolution that demolished all previous interpretations of a wrongly assumed eternal and fixed world, or one that was believed to have been divinely created recently in only six days. His concept of evolution would have a pervasive and profound influence on science, philosophy, and even theology, as well as the arts. Nothing escaped this iconoclastic view of time and change as ongoing evolution. It is within this Darwinian context that the major seminal works of both Richard Wagner and Friedrich Nietzsche are seen to reflect this enlightened awareness of dynamic reality.
In the history of music, Wagner's epic tetralogy Der Ring des Nibelungen (1876) is one of the greatest works of art in human history; it revolutionized the concept of opera in music. Likewise, Nietzsche's epic worldview in Thus Spake Zarathustra (1883-1885) is one of the greatest works of philosophy in human history; it rigorously challenged all previous humancentered ideas, beliefs, values, and perspectives. Each thinker interpreted reality in terms of a cosmic cycle.

What is not usually recognized is that both remarkably influential works are grounded in the concept of evolution. Both works offer a dynamic view of nature in general, and life in particular. Each thinker had grasped the significance of time and change, especially concerning the place of our own species within natural history. Yet, Wagner's process view of life is closed, ending with the emergence of 


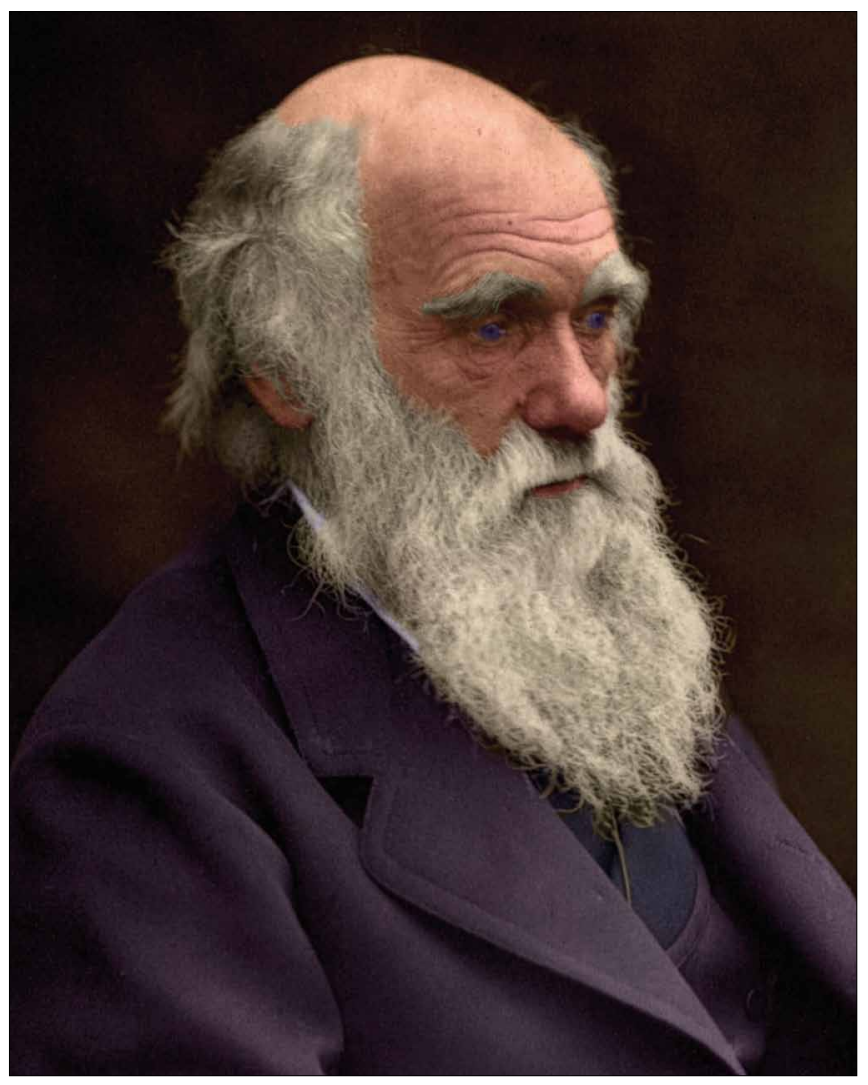

Fig. 1. Charles Darwin (Portrait).

the human being. In sharp contrast, Nietzsche's speculations on the future of evolution are open, envisioning the eventual appearance of the overhuman.

\section{INTRODUCTION}

During the Age of Enlightenment, several natural philosophers were very critical of both the Church and the State at that time; they saw these two institutions as an entrenched impediment to advances in the human world. These major thinkers took both time and change seriously, offering a dynamic interpretation of social history. They called for educational reforms, giving priority to science and reason over myths, legends, personal opinions, and religious beliefs. As such, these natural philosophers advocated using the scientific method, rigorous critical reflection, and open inquiry in both the natural and social sciences. They focused their attention on our own species, and saw process as progress. With their emphasis on empirical facts and rational concepts, these enlightened thinkers offered an intellectual atmosphere that paved the way for the emergence of a new philosophical anthropology grounded in an evolutionary framework.

The ideas and values of the Enlightenment were best expressed in the writings of the Marques de Condorcet (1734-1794). His unabashed secular worldview is reflected in Wagner's destruction of the gods and goddesses. As a result of ongoing progress in science and technology, Condorcet even envisioned a future in which the human being would enjoy an indeterminate lifespan (as did the recent philosopher Marvin Farber). Consequently, one may argue that in this bold speculation, he had anticipated the coming of a posthuman as foreshadowed in Nietzschess conception of the emergence of an overhuman.

In the middle of the nineteenth century, both Richard Wagner[i] (1813-1883) and Friedrich Nietzsche[ii] (18441900) did present a dynamic view of the world that emphasized the transitory existence of our human species within the flux of reality: Wagner's operatic masterpiece Der Ring des Nibelungen offers a cosmology within which one experiences the ongoing changes in nature from the beginning of this universe and life itself to the end of the gods and goddesses, while Nietzsche's philosophical writings, particularly his provocative book Thus Spake Zarathustra, proclaim that the human species is merely a temporary link between the earlier fossil apes and the future superior beings. These two interpretations of a dynamic world clearly reflect the evolutionary framework that was emerging in the natural and social sciences, as well as in philosophy, before the twentieth century.

\section{DARWIN \& EVOLUTION}

It was the pivotal works of Charles Darwin[iii] that presented the idea of evolution in natural philosophy as a scientific theory with far-reaching consequences for understanding and appreciating our human species as a recent part of organic nature. Darwin had taken seriously the new geological perspective with its vast periods of time and pervasive ongoing changes. He extended this dynamic view of earth history from geology to biology. His two provocative ground-breaking volumes, On the Origin of Species (1859) and The Descent of Man (1871), gave both compelling empirical evidence and convincing rational arguments for the mutability of all species, including our own, throughout organic history. As such, Darwin initiated a conceptual revolution in terms of biological evolution. One would never again look at this universe, all forms of life, and our planet as they had been seen by earlier thinkers.

In his major work On the Origin of Species, Darwin boldly presented a comprehensive but nevertheless controversial theory for the fact of organic evolution in terms of science and reason. His own evidence and experience persuaded him that species change in nature, resulting in biological evolution over sweeping eras of geological time; the awesome implications of the fossil record in the geological column were undeniable. With its penetrating insights and provocative conclusions, the Darwinian framework now seriously challenged the entrenched traditional ideas, beliefs, values, and perspectives. This growing awareness of pervasive change throughout planetary history had also emerged in the scientific and philosophical thoughts of several other significant thinkers in the nineteenth century, e.g., Ludwig Feuerbach, Ernst Haeckel, 
Georg Wilhelm Friedrich Hegel, Thomas Huxley, Jean-Baptiste Lamarck, Charles Lyell, Karl Marx, Arthur Schopenhauer, Herbert Spencer, and Alfred Russel Wallace.[iv]

Enlightened thinkers could no longer take seriously a recent creation of this world and the eternal fixity of species. For the evolutionist, everything is subject to change, from plants and animals to human societies and their cultures. However, Darwin himself never extended his evolutionary viewpoint to account for either the beginning or the end of this universe. Nor did he ever seriously consider the origin or end of life itself. But other scientists, as well as philosophers, were quick to understand and appreciate both the cosmic and the planetary consequences of the fact of evolution. Furthermore, the fact of evolution established a scientific framework for a new philosophical anthropology. Several artistic thinkers quickly incorporated an evolutionary orientation into their worldviews, including Richard Wagner and Friedrich Nietzsche. Although interpretations of evolution range from materialism, through vitalism and spiritualism, to mysticism, they all acknowledge change as being both a creative and destructive force in nature.

Reflecting the Darwinian movement, both Wagner and Nietzsche accepted and promoted an evolutionary interpretation of both the natural and social worlds; Wagner in his music-drama tetralogy Der Ring des Nibelungen[v] and Nietzsche in his colossal idea of the eternal recurrence of this same universe.[vi] In these two creative geniuses, a fixed view of nature and society is replaced by a dynamic view of all reality. A process conception of this cosmos is emphasized, which focuses on pervasive change within an evolutionary framework. Also, Wagner and Nietzsche offered both elevating and disturbing insights into human existence. One wonders what Darwin the scientist would have thought if he had experienced Wagner's monumental Ring operas in Bayreuth, and if he had read Nietzsche's metaphysical speculations on the eternal recurrence of this exact universe.

\section{WAGNER \& EVOLUTION}

Richard Wagner's idea of the music-drama as a Gesamtkunstwerk evolved out of his desire to create a new art-form that synthesized music, poetry, and drama into a total experience for the audience. He was especially influenced by Shakespeare's plays and Beethoven's symphonies, as well as the philosophical views of Feuerbach and Schopenhauer. As in the Greek tragedies, Wagner's operas are intensified representations of the human world. They also have profound philosophical significance, particularly concerning conflicting interests and struggling individuals within social development as presented in the four music-dramas of Der Ring des Nibelungen. Moreover, Wagner's leitmotif technique gave unity to his epic Ring mythology; a distinct musical theme represented major objects, events, emotions, and characters, e.g., there is a leitmotif for the magic sword and Alberich's curse. In fact, these musical themes evolve throughout this vast work. In general, one

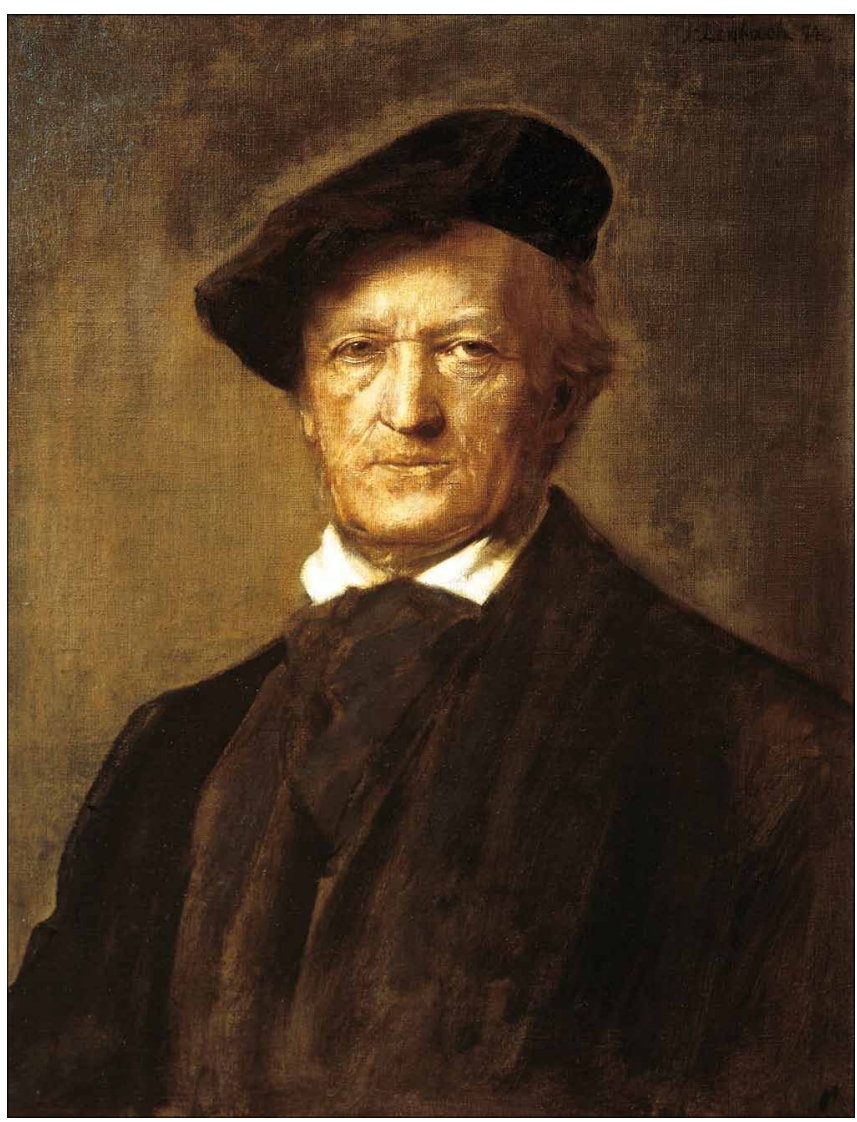

Fig. 2. Richard Wagner (Portrait).

could interpret the entire Ring cycle as a web of leitmotifs that is evolving like a huge organism! Furthermore, Wagner's Ring characters are not fixed either; individuals change from scene to scene (especially in their psychological makeup).

Wagner's Ring cosmology starts with the creation of a primordial reality. It is a three-tiered world: dwarfs live under the ground in Niebelheim, giants live on the earth in Riesenheim, and gods and goddesses live above the ground in Valhalla (the demigod Loge is able to move throughout this world). At the beginning of Das Rheingold, one hears a musical introduction to the Wagner cosmos that is quintessentially the emergence of the Rhein river. Then, a succession of important life-forms appears: fishlike Rheinmaidens, dwarfs, gods and goddesses, giants, clans of men and women (including vassals, warriors, and heroes), and eventually Siegfried as a free human being. It must be noted that not all of these creatures emerge at once. The viewer is always aware of time and transformation. The flowing Rhein, treacherous storms, a magic Tarnhelm, and the activities of Loge as the conniving demigod of magic fire are obvious symbols of pervasive change in the Ring cycle. As this tragic epic unfolds, there is both struggle and conflict in terms of wanting possession of the all-powerful Ring made from the magic Rheingold. The flux of existence sweeps characters and situations to an inevitable tragic end.

With his fluid events in Das Rheingold, Wagner does not give us a static worldview; characters and situations are con- 


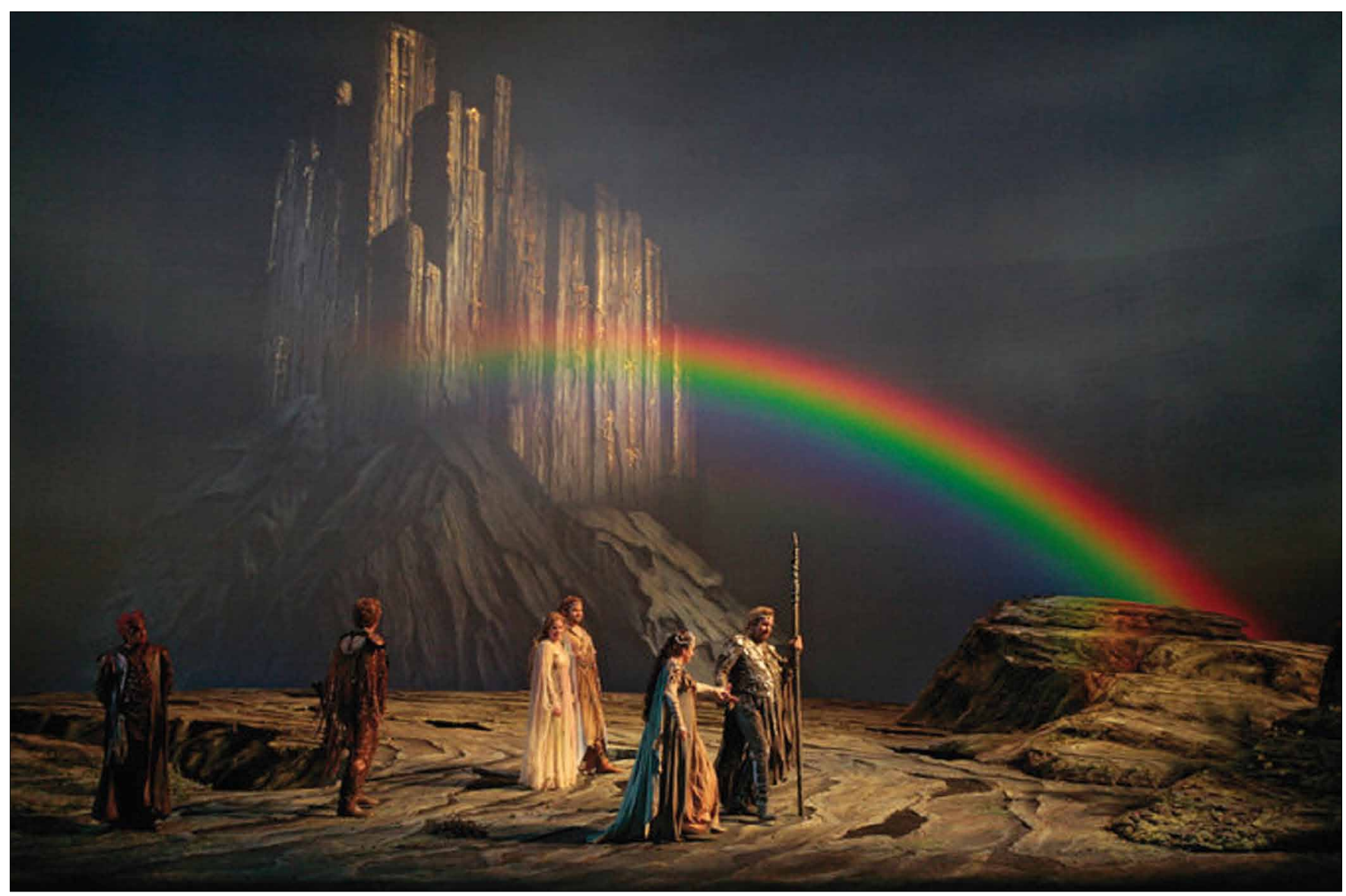

Fig. 3. Das Rheingold (Final Scene).

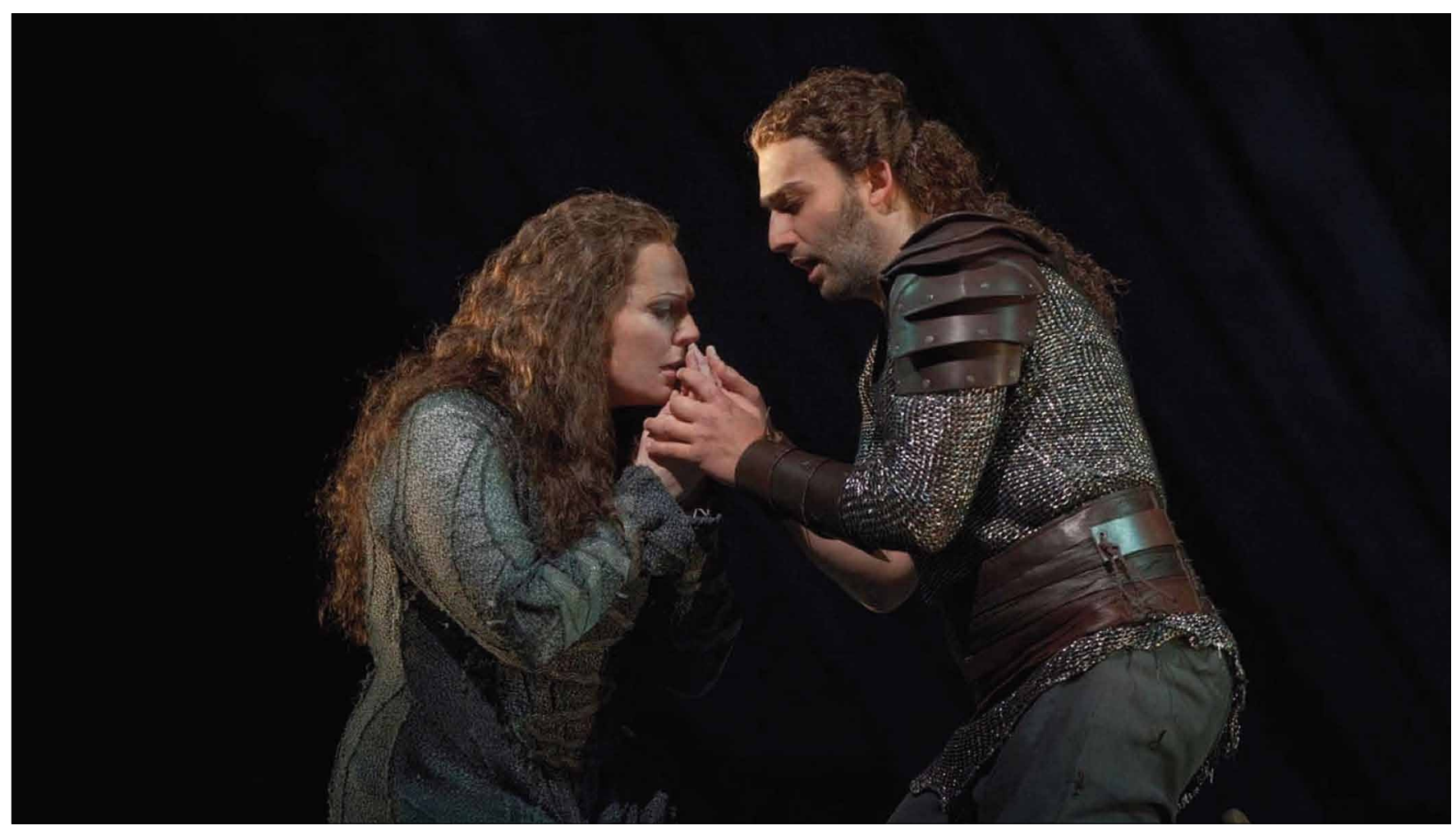

Fig. 4. Die Walküre (Siegmund \& Sieglinde). 


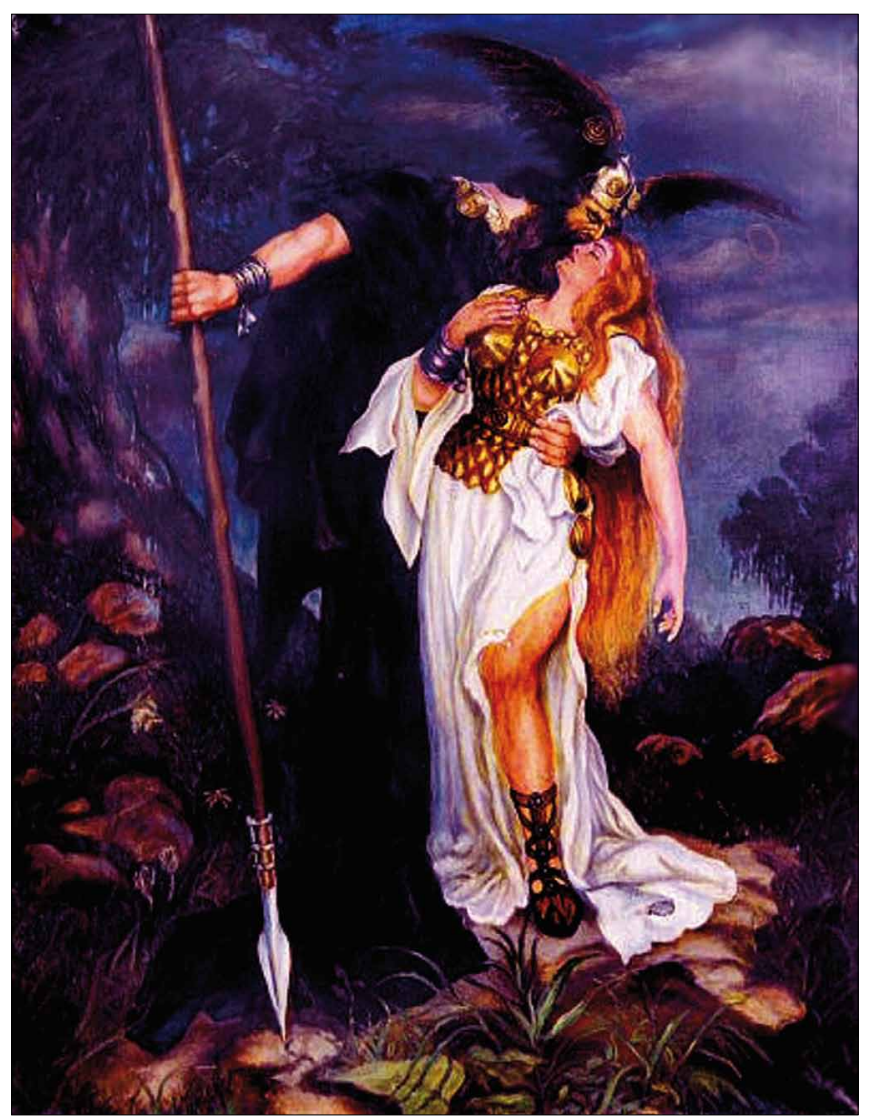

Fig. 5. Die Walküre (Wotan \& Brünnhilde). stantly changing. For example, Alberich the dwarf changes himself first into a large serpent and then into a small toad (both an early form of life on earth). Furthermore, the stolen lump of reddish gold passes first from the naïve watermaidens who had guarded it, then through ugly Alberich the underworld Nibelung (who fashioned the magic Ring) and insecure Wotan the head god, and finally to stupid Fafner the giant. Nevertheless, both Alberich and Wotan still covet the power of this now twice-cursed Ring. Erda, the all-wise earthgoddess, is aware of the tragic course of inevitable events. In Das Rheingold, she tells Wotan, chief of the gods, that: "Alles, was ist, endet. Ein düstrer Tag dämmert den Göttern: dir rat' ich, meide den Ring!'[vii] In the final scene of Das Rheingold, with false security, the gods and goddesses follow Wotan across a rainbow-bridge and into their giants-built castle Valhalla. This so-called evening of the Ring cycle presents a dramatic introduction to a Heraclitian universe of pervasive change within which there is an endless clash between good and evil.

In Die Walküre, special human beings emerge, first represented by the twins Siegmund and Sieglinde. Out of their mutual passion, Siegfried will be born. Thus, there is progress from greedy Alberich, the dwarf, to loving Siegfried, the free hero who will appear in the third music-drama. In the final scene of Die Walküre, Wotan kisses immortality away from Brünnhilde, his favorite daughter, and then leaves her on the firesurrounded Valkyries' rock. Yet, Brünnhilde is not eternally fixed in time; she will eventually be awakened by Siegfried.

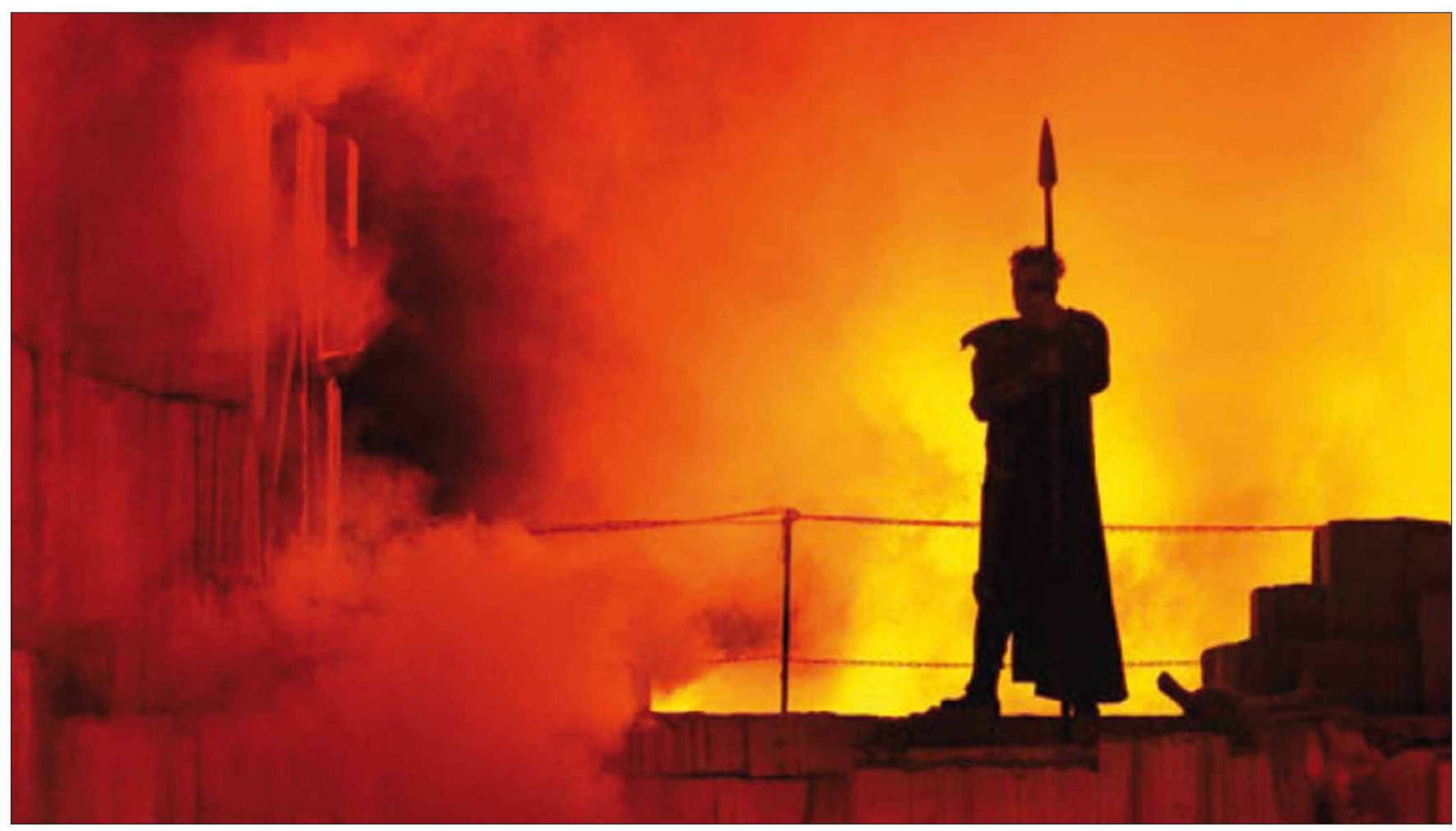

Fig. 6. Die Walküre (Final Scene). 


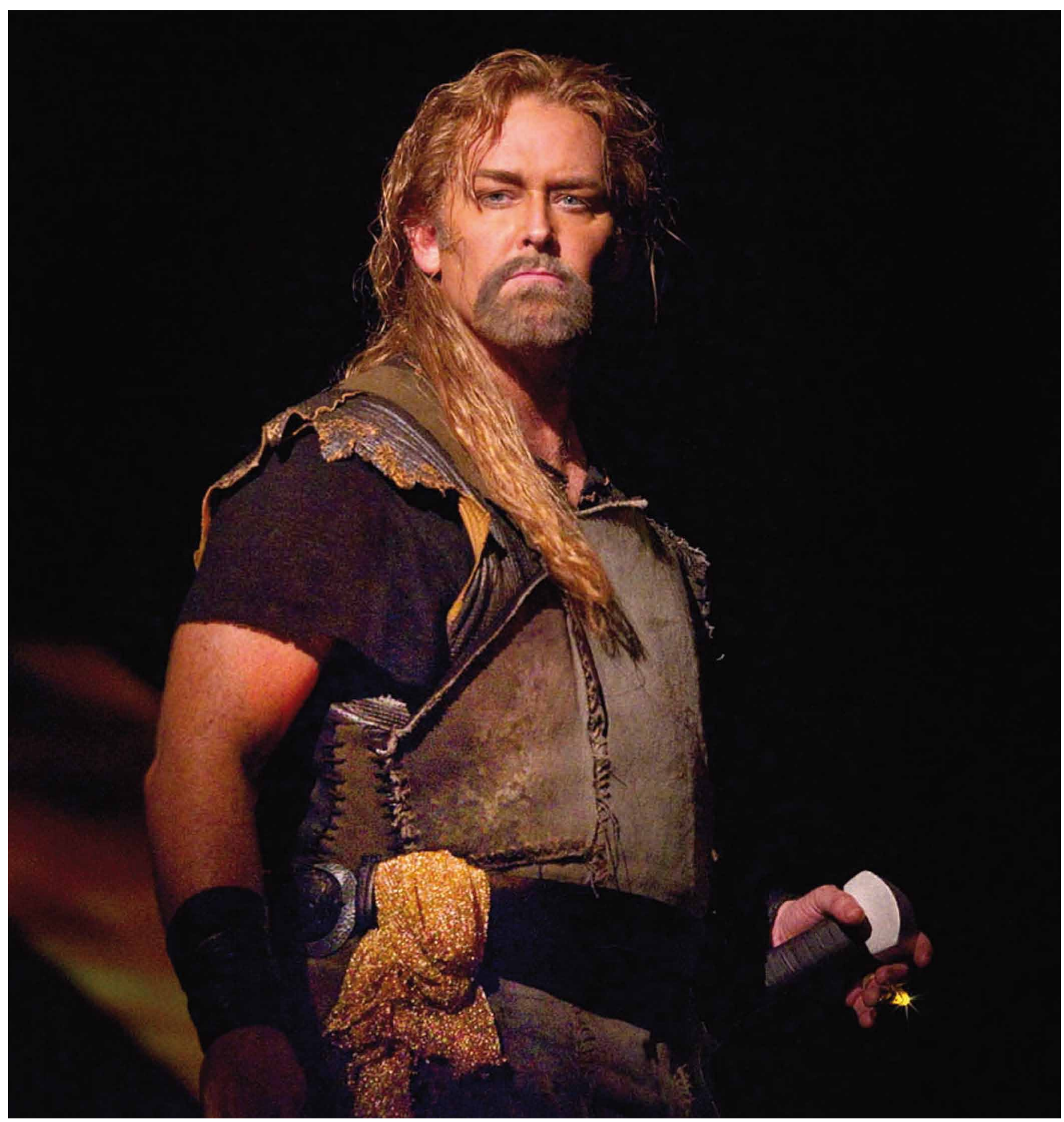

Fig. 7. Siegfried (Portrait).

In the first act of Siegfried, the free hero discovers Siegmund's magic sword. Then, Siegfried kills both the deceitful dwarf Mime and the contemptuous giant Fafner (who had changed himself into a fierce dragon), claims the Ring as his own, and finds the now-mortal Brünnhilde on the fire-surrounded Valkyries' rock. In both the characters Siegfried and Brünnhilde, the action-restricting laws and duty-bound feelings of the gods and goddesses are replaced by human emotions and human aspirations.
Extinctions are a crucial part of organic evolution. In the final act of Götterdämmerung, there is a mass extinction. The evil Hagen had desired the Ring for himself, but his having contrived the death of innocent Siegfried results in Brünnhilde setting the world ablaze; raging flames quickly consume both the mighty gathering hall of the Gibichungs and the glorious castle Valhalla. As such, Brünnhilde's selfless act brings extinction to the gods and goddesses. Likewise, all of the different races vanish from the earth due to the fire. Interestingly 


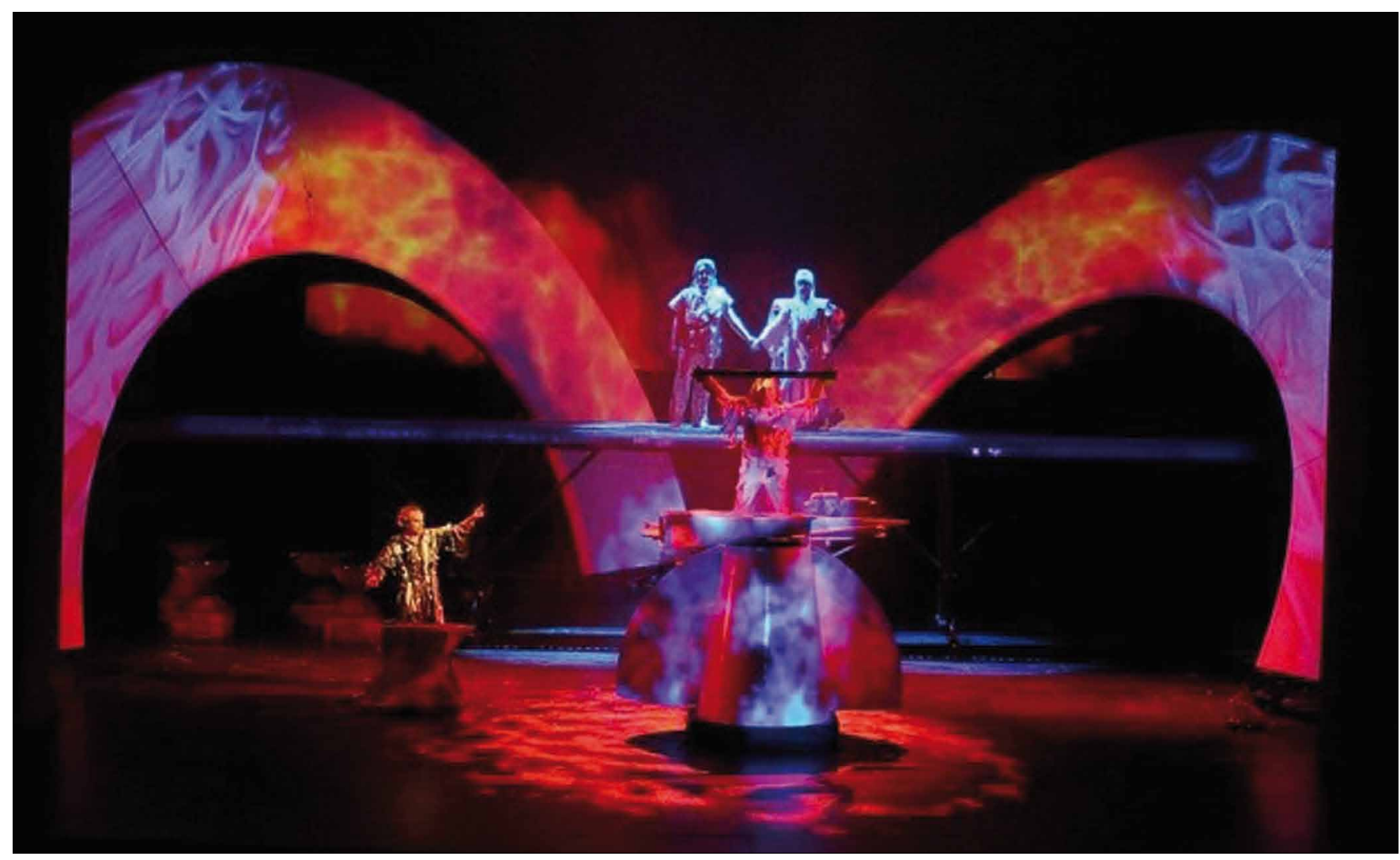

Fig. 8. Siegfried (First Act).

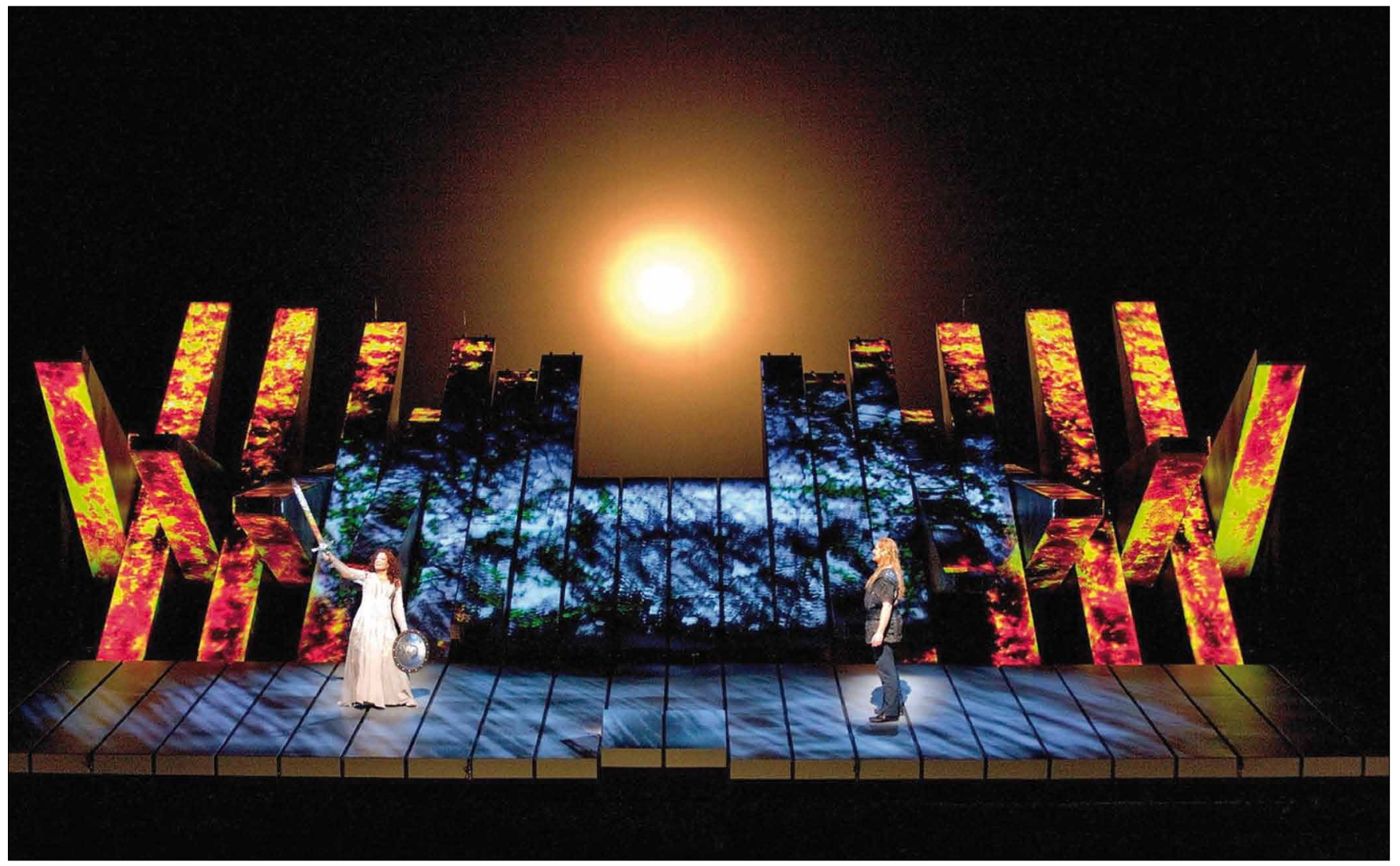

Fig. 9. Götterdämmerung (Final Act). 


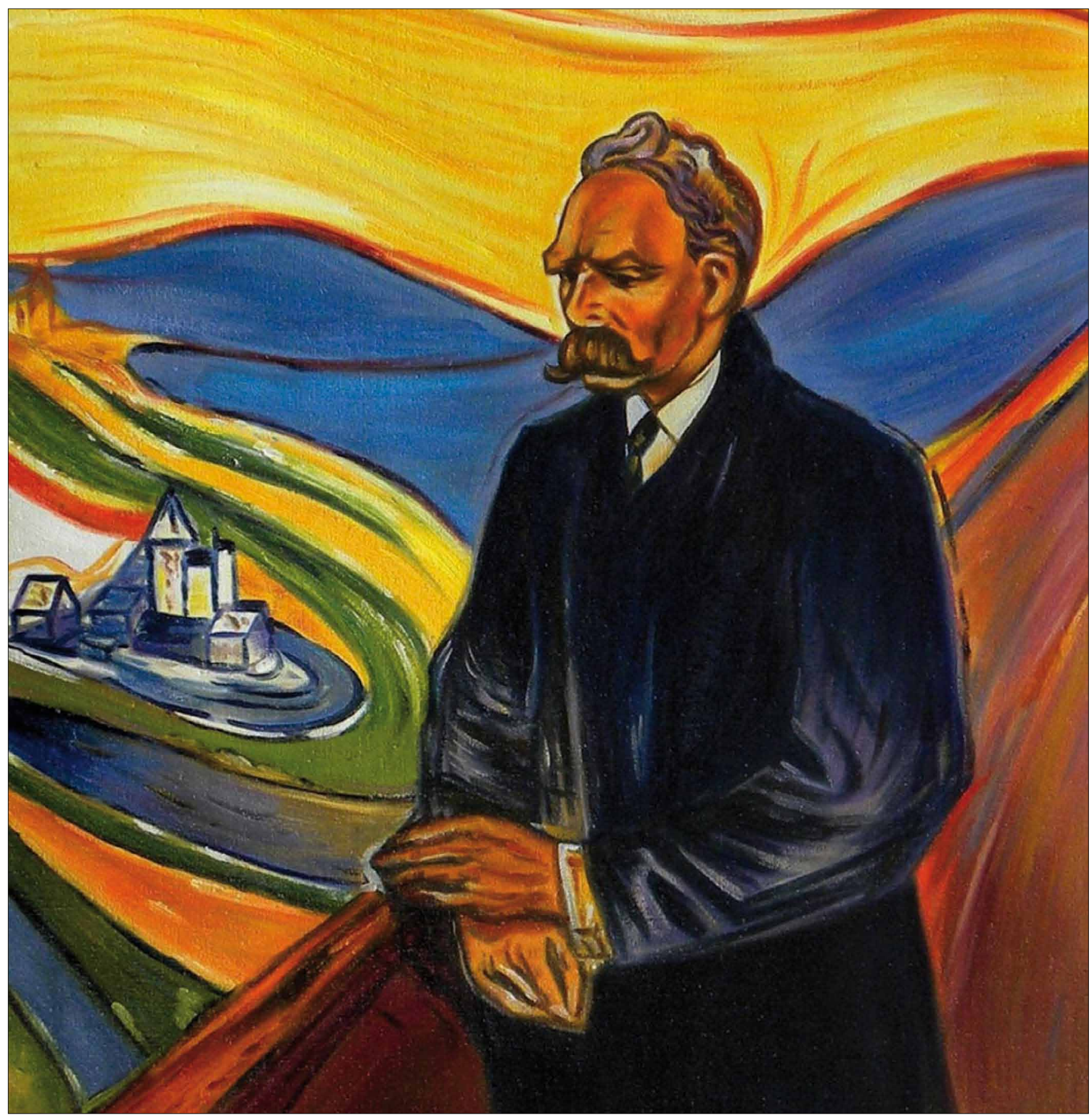

Fig. 10. Friedrich Nietzsche (Portrait).

enough, one does not see the death of Alberich. Next, with the flooding of the Rhein river, the Ring is once again with the three Rheinmaidens; appropriately, the last word uttered in the cycle was "Ring" by Hagen, just before he is drowned by the Rheinmaidens. This completes the cycle of creatures and events. As a consequence, one is back to the beginning of Wagner's mythic world. Yet, was this the first such cycle? Or, will a new cycle of evolving life-forms begin?

Wagner's Ring mythology presents a tragic interpretation of the human world within a dynamic universe; the death of
Siegfried, due to greed and evil, is followed first by a conflagration that destroys the old order of things and then a flood that redeems everything. The flowing Rhein and magic Ring endure, but one is left to wonder if evolution will now create a new and perhaps better world.

Wagner enthusiastically read the scientific writings of Darwin, but only after the publication of his Ring librettos.[viii] Nevertheless, Wagner had already been familiar with the idea of evolution from reading the philosophical works of both Feuerbach and Schopenhauer.[ix] 


\section{To live is to suffer to survive is to find some meaning in the suffering.}

\section{Friedrich Nietzsche}

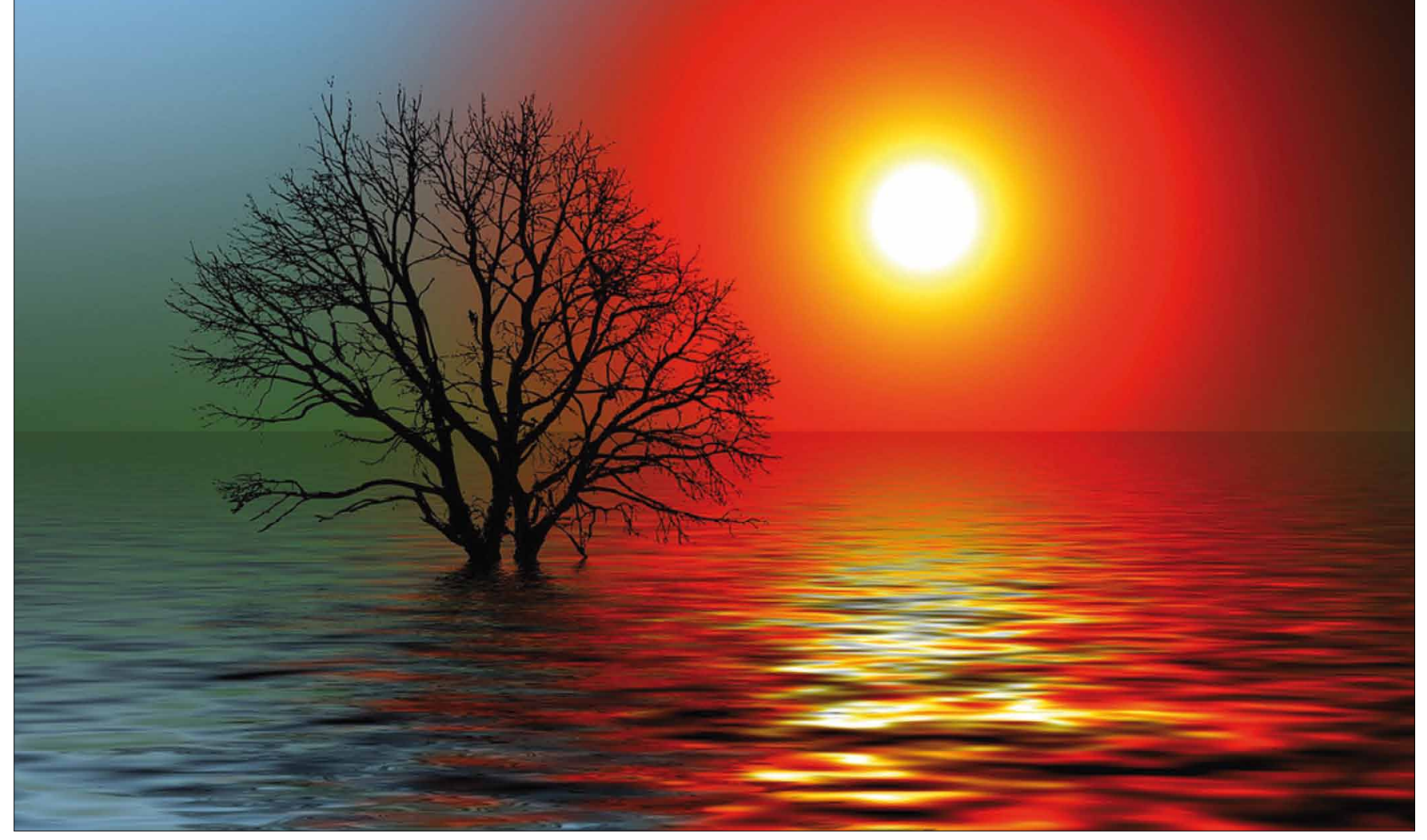

Fig. 11. Quote from Friedrich Nietzsche.

\section{NIETZSCHE \& EVOLUTION}

Going beyond Darwin, Friedrich Nietzsche offered an interpretation of nature that considered both the philosophical implications and theological ramifications of taking the fact of evolution seriously. He was not oblivious to either geological time or the paleontological record. He accepted the most controversial consequence of Darwin's theory: humankind had evolved from remote apelike ancestors, in a completely naturalistic process, without recourse to any supernatural causality. Even the mental faculties of human beings, including love and reason, were acquired during the natural course of evolutionary ascent from earlier primate forms to our own species. Today, anthropologists acknowledge the fact that the human animal differs merely in degree, rather than in kind, from the four great apes (orangutan, gorilla, chimpanzee, and bonobo). For Nietzsche, evolution is the correct explanation for organic history and (as he saw it) this process has startling inferences for both scientific cosmology and philosophical anthropology: God is no longer necessary to account for either the existence of this universe or the emergence of humankind from prehistoric apelike animals (both Wagner and Nietzsche were unabashed atheists). Moreover, this philosopher held that the factual perspective of organic evolution led to an inevitable collapse of all traditional ideas, beliefs, and values. For Nietzsche, reality is devoid of both objective meaning and spiritual purpose. Consequently, for him, there can be no eternal facts, absolute truths, fixed values, or certain morality. However, Nietzsche's philosophy challenges one to overcome suffering and obstacles in order to survive and become a creative individual who can say "Yes!" to existence. In this sense, his worldview is a positive one which stresses creativity, despite the suffering in the world. Furthermore, concerning interpreting the world, Nietzsche held that there are an infinite number of perspectives. However, his awesome conception of time and evolution as the eternal recurrence of this same material reality seems to contradict his rigorous perspectivism, i.e., Nietzsche now held the eternal recurrence to be an all-embracing true interpretation of cosmic existence.

Nietzsche had incorrectly assumed that the outcome of Darwinian evolution by natural selection could only account for the success of inferior (weak and mediocre) forms of life simply in terms of sheer numbers, e.g., the ubiquitous viruses, bacteria, insects, and fishes. And despite their astonishing success over countless millions of years, all of the past trilobites, ammonites, and dinosaurs are now extinct. The phi- 


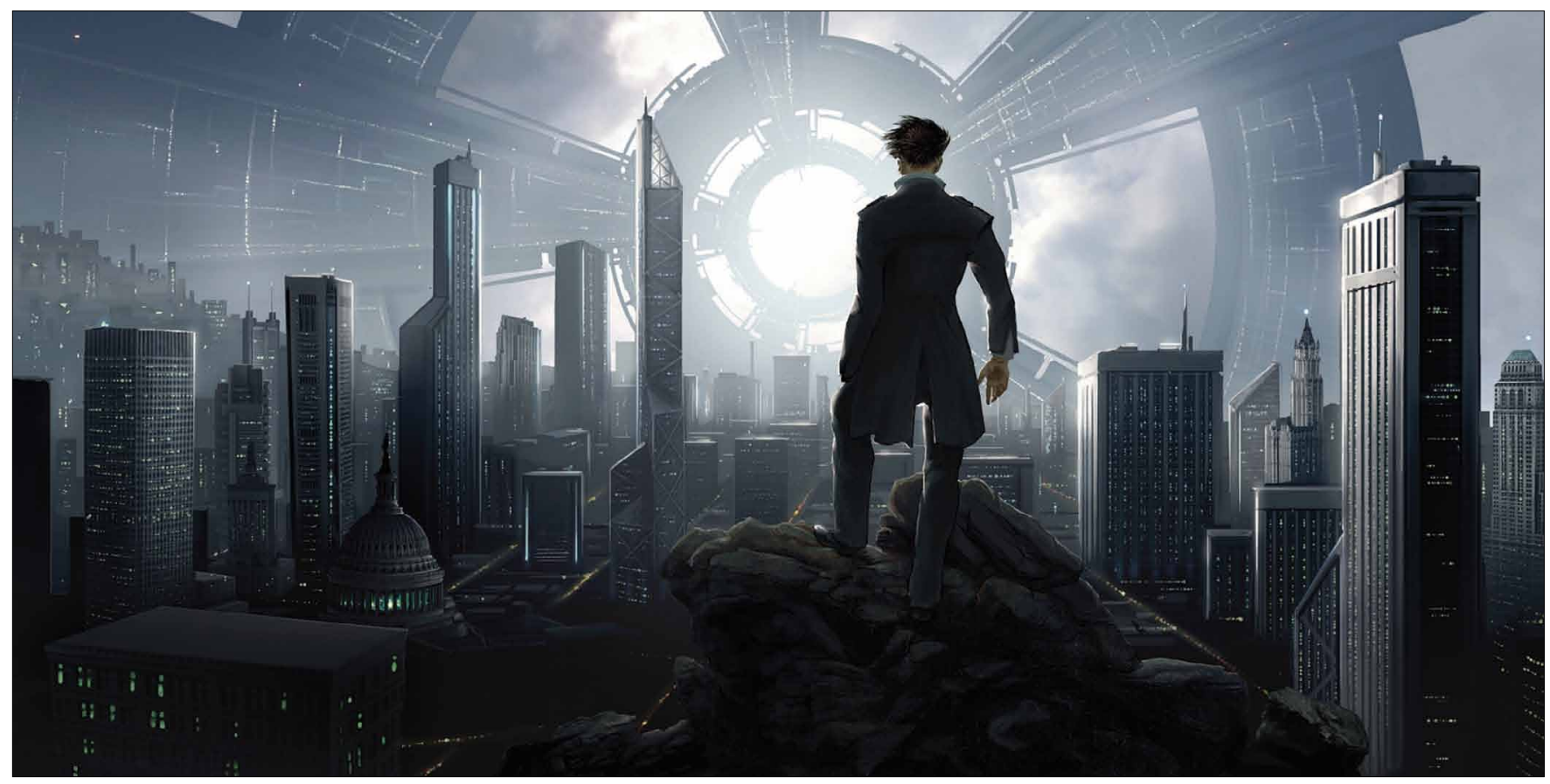

Fig. 12. Nietzsche Envisions A New Philosophical Anthropology (Illustration).

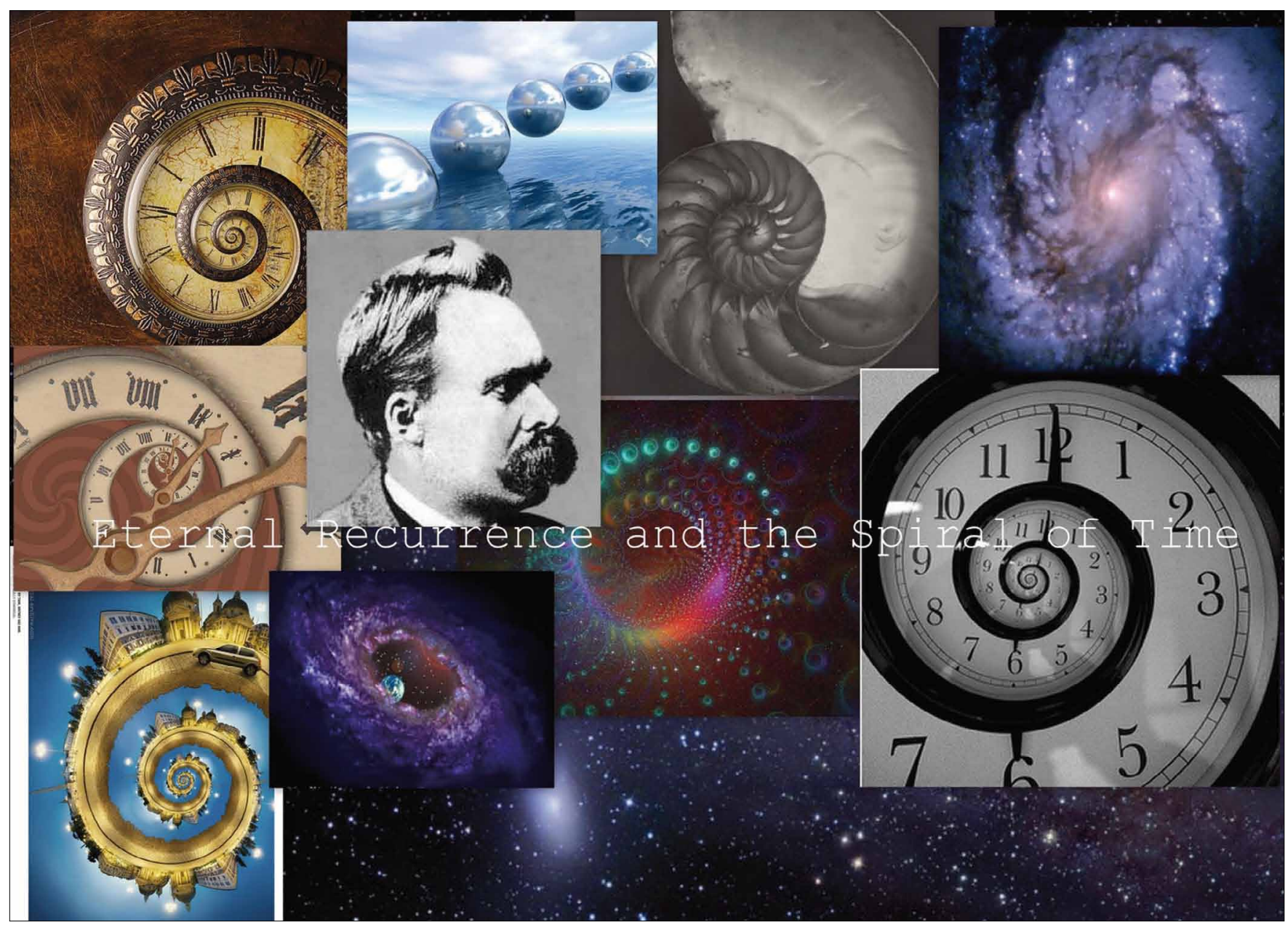

Fig. 13. Nietzsche \& Time (Illustration). 


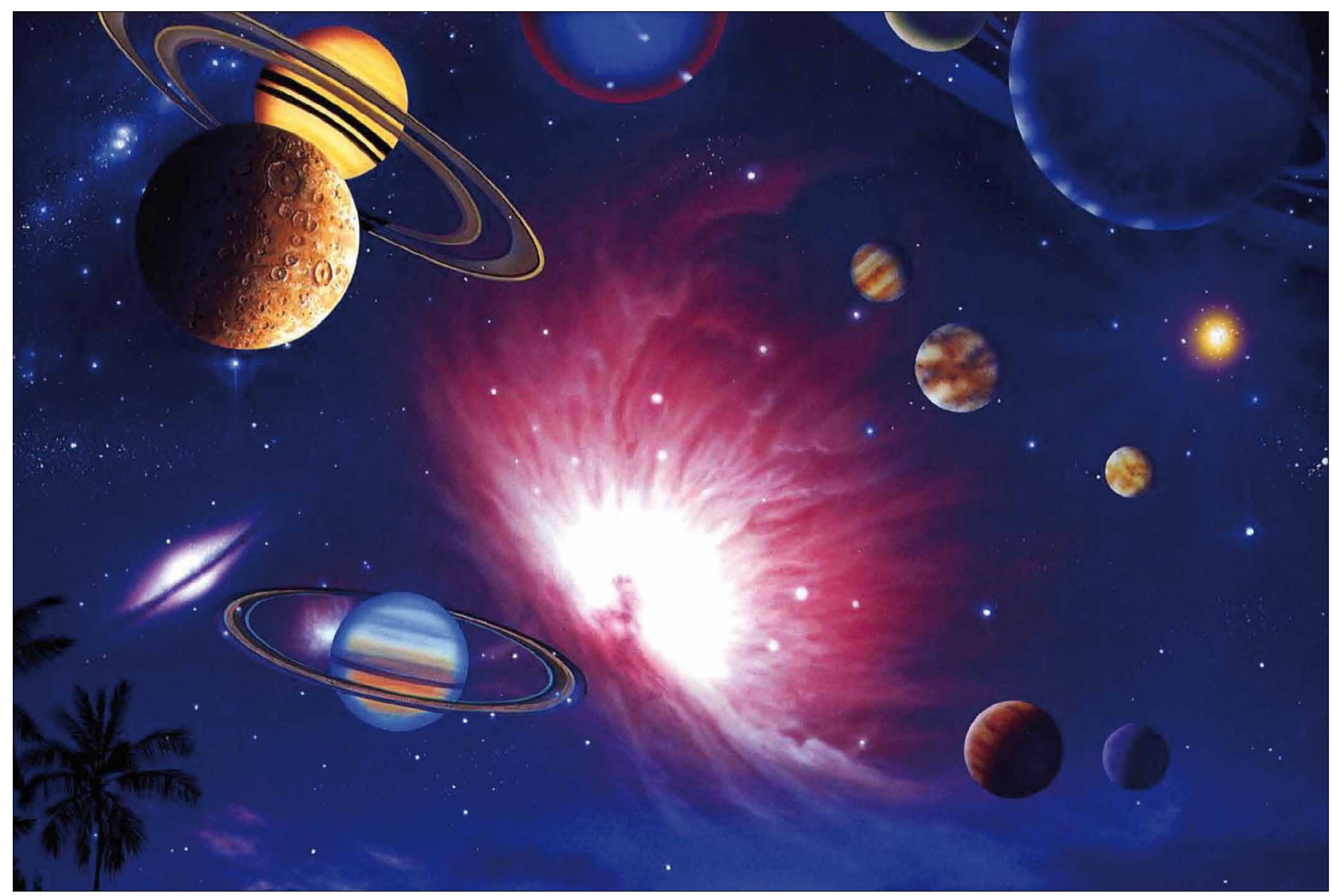

Fig. 14. Eternity (Illustration).

losopher argued that Darwin's blind species-struggle of the masses for existence in terms of adaptation and survival now needed to be replaced by his own discovery of the individual-struggle of a few for self-creation and excellence. He saw the explanatory mechanism of natural selection as merely accounting for the quantity of species within organic history. But (for him), it is a vital force that increases the quality of life-forms throughout progressive biological evolution. Nietzsche held that nature is essentially the will to power.[x] Evolving life is not only the struggle for existence, but also, and more importantly, it is the ongoing striving toward evergreater complexity, diversity, multiplicity, and creativity. In short, his vitalism had substituted Darwin's adaptive fitness with the creative power to overcome obstacles that threaten existence. As such, for Nietzsche, Darwin's explanatory mechanism of natural selection is necessary, but not sufficient, to account for creative evolution.

Reminiscent of Wagner's Ring operas, Nietzsche's process philosophy held that the evolution of organisms had its origin in primordial slime, but our species now stands high and proud at the summit of the pyramid of life. Even so, he saw a natural tendency for the human animal to evolve toward common mediocrity. However, through the will to power, each superior individual has both the potential to master his or her own life (thereby overcoming both nihilism and pessimism) and the intellect to actualize creative activity.

Nietzsche taught the historical continuity between other animals (especially the chimpanzees) and human beings. Nevertheless, he did assert that some individuals will rise far above the beasts, including beyond our own species, but this will only occur in the distant future. Furthermore, if humankind has ascended from remote fossil apes, then why should it not be followed by an even higher form of life yet to come? Just as the ape had been surpassed by our species, so will humankind be surpassed by a future form of life. According to Nietzsche, our biological species is the meaning and purpose of the earth at this time, because it is the arrow pointing from the past ape to the future overhuman; this exalted but unimaginable superior being will be as intellectually advanced beyond the present human animal as our species is now biologically advanced beyond the lowly worm! Nietzsche wrote: "What is the ape to our species? A laughing stock, a thing of shame. And just the same shall our species be to the overhuman: a laughing stock, a thing of shame. You have made your way from the worm to man, and much within you is still worm. Once you were apes, and even yet man is more of an ape than any of the apes. . . . Behold, I teach you the overhuman! The overhuman is the meaning 
of the earth. Let your will say: The overhuman shall be the meaning of the earth!" [xi]

Aware of the inevitable changes in the human world, Nietzsche envisioned the emergence of a new philosophical anthropology, i.e., the appearance of a future human world with new values far above and beyond those entrenched values that are held by our species today. No doubt, in the distant future, our descendants will exist in a world that is far beyond even Nietzsche's incredible imagination. Even so, between our species of today and the overhuman of the distant future, there is the creative higher human which has been represented so far by only a few extraordinary creative geniuses, e.g., Goethe, Beethoven, and Leonardo da Vinci (among several others). Evolution has yet to produce an overhuman on this planet. Nietzsche took time seriously on all levels of existence, from organic evolution to cosmic history. As with Wagner, Nietzsche did not foresee a final end-goal or an ultimate omega-point for human evolution on earth or elsewhere. Yet, Nietzsche was intoxicated by the concept of eternity; his cosmology embraced all past-time and all future-time within a single idea. His metaphysics is grounded in the eternal recurrence of this exact universe; an awesome concept derived from extending Heraclitus's idea of the circular flux of reality to an all-embracing dynamic cosmology. For Nietzsche, nature itself is an infinite series of identical finite cosmic cycles! As such, there is no progressive evolution from universe to universe. One is reminded of the oscillating model of this universe in modern science: a cosmos that expands and contracts forever. This eternal oscillation of identical universes precludes both any evolution from cycle to cycle and any ultimate end (final goal) for the evolving cosmos. Consequently, Nietzsche's cyclical cosmology represents Being as Becoming (existence as process), and its teleological evolution from slime to the overhuman within each cycle is strictly determined through metaphysical necessity. However, Nietzsche himself did not present a rigorous interpretation of organic evolution that is comprehensive, consistent and coherent.[xii] Even so, he realized that the human animal is not a fixed end in biological history.

Wagner and Nietzsche had taken time, change, and evolution seriously. And, both were acutely aware that this universe is totally indifferent to human existence. In fact, Nietzsche's basic ideas are implicit in Wagner's Ring operas: the death of god, re-evaluation of all values, will to power, future overhuman, and eternal recurrence. Götterdämmerung ends with the destruction of the gods and goddesses, which foreshadows $\mathrm{Ni}$ etzsche's startling claim that "God is dead!" As such, Wagner's end of all terrestrial gods and goddesses became Nietzsche's death of the transcendent God. Throughout the Ring cycle, traditional values are repeatedly challenged, e.g., the love between the twins Siegmund and Sieglinde challenges the traditional concept of marriage. The Ring includes several characters who clearly display a will to power in terms of desiring to possess the magic Ring in order to become master of this universe; this will to power is manifested in Alberich, Wotan, Mime, and Hagen. Siegfried represents a higher human being, and therefore he foreshadows the coming of an overhuman. Finally, Wagner's mythic cosmology represents a cycle which could endlessly repeat itself, as in Nietzsche's metaphysical speculation of the eternal recurrence of this same universe.

\section{CONCLUSION}

One may argue that, in the philosophy of both Wagner and Nietzsche, time as evolution is the quintessential aspect of cyclical reality. In fact, Wagner's cycle Der Ring des Nibelungen exemplifies the struggle of different life-forms (from dwarfs and giants to humans and gods) to adapt and survive in a changing world. Likewise, Nietzsche's book Thus Spake Zarathustra presents his major ideas on cosmology and values grounded in a dynamic view of all existence.

Interestingly enough, Nietzsche died in 1900, not living into the twentieth century that witnessed those military wars and intellectual battles which resulted from an ongoing re-evaluation of all values. The struggle for existence still continues, not only in the organic realm, but also in the human world. Change embraces both geological structures and biological species, as well as societies and cultures. And in the organic flux of earth history, few life-forms escape extinction (although new species have continuously emerged through ongoing biological evolution).

Today, controversy still surrounds the works of Wagner and Nietzsche, just as it does the fact of evolution. Traditions resist changes in ideas, beliefs, values, and perspectives. Wagner and Nietzsche were painfully aware of this resistance to change. Yet, scientific progress has confirmed the recent and vulnerable evolutionary position of our own species within cosmic nature.

In this century, the converging human world is resulting in the ongoing clashes among societies with their different cultures (especially in terms of opposing beliefs). Wagner portrayed the clash of values in his Ring tetralogy. Of special significance is the sharp contrast between duty (Wotan) and inclination (Brünnhilde); Wagner's romanticism favoured human emotions over godly laws. Nietzsche saw the evolution of human values from the present slave morality of the masses, with their false ideas and pointless activities, to the future master morality of superior individuals, with their enlightened ideas and creative activities free from stagnant and oppressive mediocrity. Superior individuals create their own values beyond traditional good and evil. But just as some earlier (lower) life-forms still exist, e.g., the sharks and cockroaches, so the wretched last man will inhabit this planet, along with the noble overhuman, until the end of the earth. The last man may be seen as an example of devolution in our species, in sharp contrast to the future overhuman which is the ultimate goal of human evolution.

Finally, today one may enjoy both attending Wagner's Ring operas and reading Nietzsche's Zarathustra ideas. Both visions of reality embraced the evolutionary framework, while holding an analytic mirror to the human situation. Both 


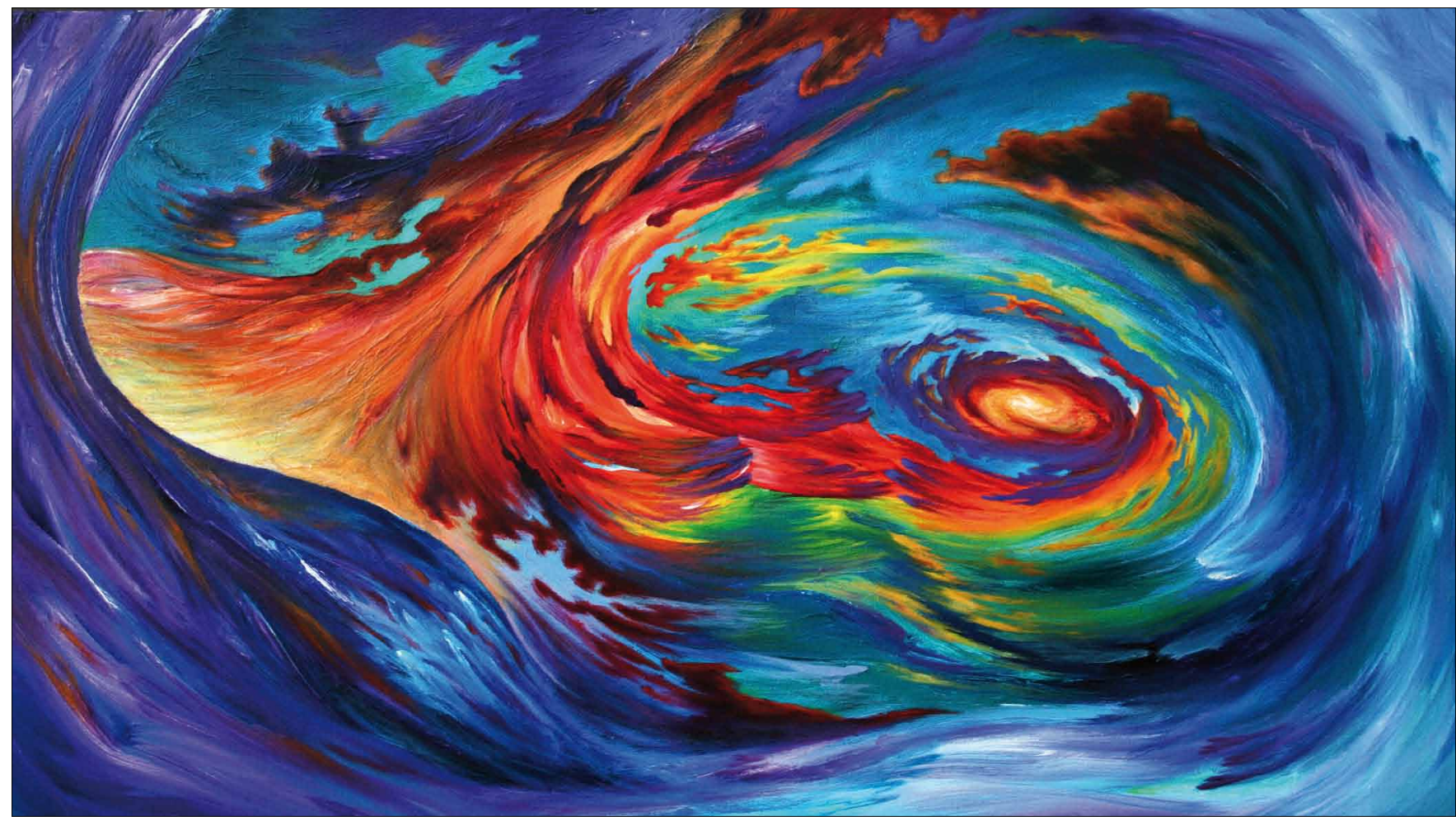

Fig. 15. Creation (Illustration).

works offered subtle and bold interpretations of dynamic existence. Yet, Wagner had not speculated on what would follow after the destruction of this world. For Nietzsche, however, the end of this evolving universe is followed by another finite but identical cosmic cycle.

\section{EPILOGUE: SOME FINAL THOUGHTS}

Although Wagner's Siegfried is a heroic character, he is nevertheless merely a human being who never progresses beyond the human level of existence. In fact, his tragic death ends the race of human beings. However, in sharp contrast, Nietzsche's overhuman is a superior being of the future who has evolved far beyond the "human, all too human" level of existence.

With the will to evolve and dynamic integrity, and in terms of ongoing advances in nanotechnology and bioengineering, scientists will more and more be able to enhance our own species. Continuous human intervention allows for an emerging teleology that will eventually result in the designing of a transhuman, i.e., the appearance of the new species Homo futurensis. Even further changes to this new species will result in the emergence of the posthuman as a new genus that represents the immortal cosmic-overbeing, i.e., the realization of Nietzsche's future overhuman as an entity as superior to our present genus as it is superior to the past lowly worm! This biotechnic form will be an entity capable of existing among the stars.

Obviously, neither Richard Wagner nor Friedrich Nietzsche could have considered the possibility of exobiology and exoevolution. Their evolutionary viewpoints, even as advanced as they were, are limited only to planet earth. Nevertheless, in a creative universe, they each saw creative evolution resulting in the emergence of a creative human being.

\section{NOTES}

In 2016, the opera world celebrates the 140th anniversary of the first-ever complete production of the four-part Ring cycle production which was presented in Richard Wagner's own festival-theater in Bayreuth, Germany, in 1876. Both the Ring operas and the festival-theater had been made possible through the extremely generous patronage of King Ludwig II of Bavaria. In fact, Friedrich Nietzsche himself had attended Bayreuth for the first Ring cycle festival (the elder composer and the young philosopher had been friends for ten years).

The best audio CD version of Der Ring des Nibelungen remains the splendid ground-breaking first-ever complete recording conducted by Sir Georg Solti and now available in a super deluxe edition from Decca (2012). An impressive DVD video version of the complete Ring cycle is the Meropolitan Opera's traditional production conducted by James Levine and still available from Deutsche Grammophon (2002).

Over the years, Prof. Dr. Dr. H. James Birx has attended numerous productions of Wagner's Ring operas, from Bayreuth, 
Berlin, Munich, Vienna and Weimar to Boston, Chicago, New York City, Seattle and Toronto.; Das Rheingold is his favorite music-drama. He has also edited Nietzsche's Thus Spake Zarathustra and visited the philosopher's major work sites in Germany and Switzerland. Some of the insights and ideas within this article were first expressed by Prof. Birx in several presentations that he has given for The Image conference at Imperial College London in 2015 and for the Faculty of Philology at the University of Belgrade in 2011, 2013, and 2014.

\section{ENDNOTES}

[i] For a general introduction to Wagner, refer to Birx, H.J. (2006): Wagner, Richard. In: Encyclopedia of Anthropology, vol. 5, 22932295. See also Culshaw, J. (1978): Wagner: The Man and His Music; Westernhagen, C. von. (1978): Wagner: A Biography.

[ii] For a general introduction to Nietzsche, refer to Birx, H.J. (2006): Nietzsche, Friedrich. In: Encyclopedia of Anthropology, vol. 4, 17411745. For recent works on Nietzsche's life, refer to Cate, C. (2005): Friedrich Nietzsche; Fink, E. (2003): Nietzsche's Philosophy; Köhler, J. (2002): Zarathustra's Secret: The Interior Life of Friedrich Nietzsche; Safranski, R. (2001): Nietzsche: A Philosophical Biography. See also Chamberlain, L. (1999): Nietzsche in Turin: An Intimate Biography; Hayman, R. (1980): Nietzsche: A Critical Life; Hollingdale, R.J. (1965): Nietzsche: The Man and His Philosophy; Kaufmann, W. (1974): Nietzsche: Philosopher, Psychologist, Antichrist; Magnus, B. and K.M. Higgins, eds. (1996): The Cambridge Companion to Nietzsche; Vattimo, G. (2002): Nietzsche: An Introduction; Welshon, R. (2004): The Philosophy of Nietzsche; Wicks, R. (2007): Nietzsche.

[iii] For a general introduction to Darwin, refer to Birx, H.J. (2006): Darwin, Charles. In: Encyclopedia of Anthropology, vol. 2, 687-692. For a recent biography on Darwin, see also Aydon, C. (2002): Charles Darwin. For a comprehensive introduction to Darwin's life, refer to Browne, J. (1996): Charles Darwin: A Biography, and Browne, J. (2003): Charles Darwin: A Biography.

[iv] For an historical introduction to the major philosophies of evolution, refer to Birx, H.J. (1984): Theories of Evolution. See also Birx, H.J. (2010): Evolution: As I See It. In: Anthropologia Integra, 1(2): 7-10.

[v] For different analyses of Der Ring des Nibelungen, refer to Bassett, P. (2003): The Nibelung's Ring: A Guide to Wagner's Der Ring des Nibelungen; Cook, D. (1992): I Saw the World End: A Study of Wagner's Ring; Culshaw, J. (1967): Ring Resounding; Donnington, R. (1984): Wagner's Ring and Its Symbols; Fisher, B. (2002): Wagner's The Ring of the Nibelung; Kitcher, P. and R. Schacht. (2004): Finding an Ending: Reflections on Wagner's Ring; May, T. (2004): Decoding Wagner: An Invitation to His World of Music, 105-172; Millington, B. (2006): The New Grove Guide to Wagner and His Operas, 95-132.

[vi] For various interpretations of Nietzsche's concept of the eternal recurrence, refer to Heidegger, M. (1991): Nietzsche; Jaspers, K. (1969): Nietzsche: An Introduction to the Understanding of His Philosophical Activity; Klossowski, P. (1997): Nietzsche and the Vicious Circle; Löwith, K. (1997): Nietzsche's Philosophy of the Eternal Recurrence of the Same; Pearson, K.A. (1997): Viroid Life: Perspectives on Nietzsche and the Transhuman Condition. See also Birx, H.J. (1984):
Theories of Evolution, 184-198. For a modern interpretation of our species in this universe, refer to Milićević, B. (2012): Humans in the Cosmos! In: Nietzsche \& 2001: A Space Odyssey, 42-43.

[vii] Folksausgabe.

[viii] Of particular significance concerning Wagner's reading the works of Darwin, refer to Gregor-Dellin, M. and D. Mack. (1980): Cosima Wagner's Diaries, vol. 1, 22, 211, 660, 701, 732, 850, vol. 2, 505, 507, 514, 594, 985, 989.

[ix] For a groundbreaking and insightful analysis of the relationship between Schopenhauer and Nietzsche, in terms of evolution, refer to Simmel, G. (1991): Schopenhauer and Nietzsche. See also Birx, H.J. (1984): Theories of Evolution, 83-86, 184-198.

[x] For an excellent analysis of Nietzsche's concept of the will to power, refer to Sorgner, S.L. (2007): Metaphysics without Truth: On the Importance of Consistency Within Nietzsche's Philosophy. See also Reginster, B. (2006): The Affirmation of Life: Nietzsche on Overcoming Nihilism.

[xi] KSA.

[xii] Refer to $K S A$, NF, 13, 316-317. For two recent works on Nietzsche and evolutionary biology, refer to Moore, G. (2002): Nietzsche, Biology and Metaphor; Richardson, J. (2004): Nietzsche's New Darwinism.

\section{ACKNOWLEDGEMENTS}

I am very grateful to my dear friend Prof. Branko Milićević for both his ongoing encouragement and his expert technical assistance during the preparation of the fifteen illustrations for this article. In the Faculty of Philology at the University of Belgrade, I was given exceptional editorial help by the young scholars Marko Bozovic and Alexander V. Tenodi, as well as benefited from astute reviews by Thomas Mark Koehler, Ryan J. Trubits and Shrikant Vardhan in New York and Pamela Rae Huteson in Alaska. Prof. Dr. Ljiljana Markovic graciously made possible all of my academic presentations on Richard Wagner and Friedrich Nietzsche during my status as a distinguished visiting professor in the Faculty of Philology at the University of Belgrade.

\section{SELECTED REFERENCES}

Aydon, Cyril (2002): Charles Darwin. London: Robinson.

Birx, H. James (1984): Theories of Evolution. Springfield: Charles C Thomas, esp. 184-198.

Birx, H. James (1993): Introduction in Nietzsche, Friedrich, Thus Spake Zarathustra. Amherst: Prometheus Books, 13-27. Original work published 1883-1885.

Birx, H. James (2006): Darwin, Charles. In: Birx, H. James, ed., Encyclopedia of Anthropology. Thousand Oaks: SAGE Publications, vol. 2, 687-692.

Birx, H. James (2006): Nietzsche, Friedrich. In: Birx, H. James, ed., Encyclopedia of Anthropology. Thousand Oaks: SAGE Publications, vol. 4, 1741-1745.

Birx, H. James (2006): Wagner, Richard. In: Birx, H. James, ed., Encyclopedia of Anthropology. Thousand Oaks, SAGE Publications, vol. 5, 2293-2295. 
Birx, H. James (2009): Darwin, Charles (1809-1882). In: Birx, H. James, ed., Encyclopedia of Time: Science, Philosophy, Theology, \& Culture. Thousand Oaks: SAGE Publications, vol. 1, 263-269.

Birx, H. James (2009): Wagner, Richard (1813-1883). In: Birx, H. James, ed., Encyclopedia of Time: Science, Philosophy, Theology, \& Culture. Thousand Oaks: SAGE Publications, vol. 3, 1415-1417.

Birx, H. James (2010): Evolution: As I See It. Anthropologia Integra, 1(2), 7-10.

Birx, H. James (2010): Evolution: Science, Anthropology, and Philosophy. In: Birx, H. James, ed., 21st Century Anthropology: A Reference Handbook. Thousand Oaks: SAGE Publications, vol. 2, 586-599.

Birx, H. James (2010): Preface. In: Sorgner, Stefan Lorenz \& Oliver Further, eds., Music in German Philosophy: An Introduction. Chicago: University of Chicago Press, ix-xii.

Birx, H. James (2015): Identity \& Evolution: Prehumans, Humans, Transhumans, Posthumans. In: Humanism: Culture or Illusion? Belgrade: Faculty of Philology, University of Belgrade, vol. 1, 177-200.

Blunt, Wilfrid \& Michael Petzet (1970): The Dream King: Ludwig II of Bavaria. New York: Viking Press.

Browne, Janet (1996): Charles Darwin: A Biography, vol. 1 - Voyaging. Princeton: Princeton University Press.

Browne, Janet (2003): Charles Darwin: A Biography, vol. 2 - The Power of Place. Princeton: Princeton University Press.

Cate, Curtis (2005): Friedrich Nietzsche. New York: Overlook Press.

Cooke, Deryck (1992): I Saw the World End: A Study of Wagner's Ring. Oxford: Oxford University Press.

Culshaw, John (1967): Ring Resounding. New York: Viking Press.

Culshaw, John (1978): Wagner: The Man and His Music. New York: Metropolitan Opera Guild.

Darwin, Charles (2000): The Autobiography of Charles Darwin. Darwin, Francis (Ed.), Amherst: Prometheus Books. See Introduction by H. James Birx, vii-xxii. Original work published 1887.

Donnington, Robert (1984): Wagner's Ring and Its Symbols. New York: Faber \& Faber.

Farber, Marvin (1968): Basic Issues in Philosophy: Experience, Reality, and Human Values. New York: Harper Torchbooks, esp. 219-222.

Fink, Eugen (2003): Nietzsche's Philosophy. London: Continuum.

Freud, Sigmund (1987): A Phylogenetic Fantasy: Overview of the Transference Neuroses. Cambridge, Massachusetts: Harvard University Press/Belknap Press. Original work written 1915.

Geek, Martin (2013): Richard Wagner: A Life in Music. Chicago: Chicago University Press.

Goodell, Edward (1994): The Noble Philosopher: Condorcet and the Enlightenment. Amerst: Prometheus Books.

Grey, Thomas S., ed. (2008): The Cambridge Companion to Wagner. Cambridge: Cambridge University Press, esp. 74-84.

Hayman, Ronald (1980): Nietzsche: A Critical Life. Oxford: Oxford University Press.

Heidegger, Martin (1991): Nietzsche, 4 vols. New York: HarperSanFancisco/ HaperCollins.

Hollingdale, R. J. (1965): Nietzsche: The Man and His Philosophy. Baton Rouge: Louisiana State University Press.

Jaspers, Karl (1969): Nietzsche: An Introduction to the Understanding of His Philosophical Activity. Chicago: Gateway.

Kaufmann, Walter (1974): Nietzsche: Philosopher, Psychologist, Antichrist, 4th ed. Princeton: Princeton University Press.

Klossowski, Pierre (1997): Nietzsche and the Vicious Circle. Chicago: Chicago University Press.

Köhler, Joachim (2002): Zarathustra's Secret: The Interior Life of Friedrich Nietzsche. New Haven: Yale University Press.

Lee, M. Owen (1998): Wagner's Ring: Turning the Sky Round (An Introduction to the Ring of the Nibelung). New York: Proscenium/Limelight.

Loeb, Paul S. (2010): The Death of Nietzsche's Zarathustra.Cambridge: Cambridge University Press.

Löwith, Karl (1997): Nietzsche's Philosophy of the Eternal Recurrence of the Same. Chicago: University of Chicago Press.

Magee, Bryan (1988): Aspects of Wagner, 2nd ed. Oxford: Oxford University Press.

May, Thomas (2004): Decoding Wagner: An Invitation to His World of Music. Swavesey: Amadeus Press.
Michalski, Krzysztof (2012): The Flame of Eternity. An Interpretation of Nietzsche's Thought. Princeton: Princeton University Press, esp. 150-208.

Milićević, Branko (2012): Humans in the Cosmos! In: Birx, H. James, ed., Nietzsche \& 2001: A Space Odyssey. Belgrade: University of Belgrade Library, 42-43.

Moore, Gregory (2006): Nietzsche, Biology and Metaphor. Cambridge: Cambridge University Press.

Nietzsche, Friedrich (1969): Thus Spoke Zarathustra: A Book for Everyone or No One. New York: Penguin Classics. Original work published 1883-1885.

Pearson, Keith Ansell (1997): Viroid Life: Perspectives on Nietzsche and the Transhuman Condition. London: Routledge.

Pearson, Keith Ansell, ed. (2009): A Companion to Nietzsche. Oxford: WileyBlackwell.

Rackham, Arthur (2009): Rackham's Color Illustrations for Wagner's "Ring”. New York: Dover.

Reginster, Bernard (2006): The Affirmation of Life: Nietzsche on Overcoming Nihilism. Cambridge: Harvard University Press.

Richardson, John (2004): Nietzsche's New Darwinism. Oxford: Oxford University Press.

Safranski, Rudiger (2001): Nietzsche: A Philosophical Biography. New York: W.W. Norton.

Shaw, George Bernard (2010): The Perfect Wagnerite: A Commentary on the Nibelung's Ring. New York: Dover.

Simmel, Georg (1991): Schopenhauer and Nietzsche. Champaign: University of Illinois Press.

Spotts, Frederic (1994): Bayreuth: A History of the Wagner Festival. New Haven: Yale University Press.

Treadwell, James (2003): Interpreting Wagner. New Haven: Yale University Press.

Vaihinger, Hans (2008): The Philosophy of "As If": A System of the Theoretical, Practical and Religious Fictions of Mankind. New York: Routledge. Original work published in 1924.

Velikovsky, Immanuel (2009): Earth in Upheaval. London: Paradigma Ltd. Original work published 1955.

Westernhagen, Curt von (1978): Wagner: A Biography, 2 vols. Cambridge: Cambridge University Press.

Wicks, Robert (2007): Nietzsche. Oxford: Oneworld Publications.

Young, Julian (2010): Friedrich Nietzsche: A Philosophical Biography. Cambridge: Cambridge University Press.

\section{AUTHOR}

Birx, H. James (1. 6. 1941, Canandaigua, New York, USA) is an American anthropologist and philosopher, an exemplary professor of anthropology at Canisius College, and a permanent distinguished visiting professor in the Faculty of Philology at the University of Belgrade. He received both an M.A. in anthropology and a Ph.D. with distinction in philosophy from the State University of New York-University at Buffalo. Dr. Birx has been an invited visiting scholar at the University of Cambridge and twice at Harvard University. For SAGE Publications, he both edited and contributed to the 2-volume 21st Century Anthropology: A Reference Handbook, the 3-volume Encyclopedia of Time: Science, Philosophy, Theology, \& Culture, and the awardwinning 5-volume Encyclopedia of Anthropology (2006). Dr. Birx has authored six books, including the award-winning Theories of Evolution (1984). His professional publications also include over 400 essays, chapters, articles, book reviews, introductions, and encyclopedia entries. His academic interests focus on topics in process philosophy, biological anthropology, and the evolutionary sciences. In June 2011, Dr. H. James Birx was a Wagner Fellow at Das Lohengrin-Haus in Graupa/ Dresden, Germany. On 25 March 2016, he was elected into the Royal Academy of Scientists \& Artists (SKANU) in Belgrade, Serbia.

CONTACT: Professor H. James Birx, Canisius College, Anthropology Division, 2001 Main Street, Buffalo, New York 14208-1098 USA, or E-mail: belgradejim@hotmail.com 